\title{
Nazio kulturalaz ohar zenbait
}

\author{
Paulo IzTUeta Armendariz \\ UPV/EHUko irakasle ohia
}

\section{(Some notes on a cultural nation)}

Lantxo hau euskal kulturgintzan aspaldiko bidelagun izan dudan Jesus Mari Larrazabali eskaintzen diot, aurrerantzean ere kuraiaz jarrai dezan opatuz.

DOI: $10.1387 /$ gogoa.20363

\begin{abstract}
This work argues that the Basque Country — the country of Basque language - is an ethnic and cultural, and at the same time, civic nation, and after discussing the notion following the works of Todorov, Artaud, Rousseau, Connor and Tonnies, among others, it aims at clarifying the distinction between ethnos and pathos. The sovereignty of a country is the source of ethnos, whereas the sovereignty of the city is the source of demos. Both are found in a political community, either in the made up nation built by the state or in a historical nation without a state. The problem is to what extent these two concepts are compatible and to what extent are not, especially when the transversality of social phenomena makes a leap from the right to self-determination of the countries to the citizens' right to decide. This problem is manifest in the case of the Basque Country and Catalonia, which want to built their independent states or republics. The citizenship has its roots in the state. And when the state sees its territorial unity to be in danger, it ignites the ghost of two communities in the subdued nations. In the concluding section, the recovery of Basque language and the territorial unity are taken as an indispensable basis, among others for a future independent Basque Country. It is also reminded that state-nations are in crisis and national liberations on the rise. In Europe there were 24 states at the beginning of $20^{\text {th }}$ century; today there are more than 50.
\end{abstract}

Keywords: nation, state, community, identity, citizenship, people. 


\section{Laburpena}

Euskal Herria -euskararen herria- nazio etniko eta kulturala eta, aldi berean, zibikoa ere badela enuntziatu eta, besteak beste, Todorov, Artaud, Rousseau, Connor eta Tonniesek diotenaren argitan mugatu ondoren, ethnosen eta demosen arteko bereizketa zertan datzan zehazten da lan honetan. Ethnosek herri-subiranotasuna du iturri; demosek, aldiz, hiri-subiranotasuna. Biak gauzatzen dira komunitate politiko batean, nola estatuak eraikitako nazio asmatuan hala estaturik gabeko nazio historiko batean. Bi kontzeptu horiek zein neurritan diren bateragarriak, zeinetan ez, da arazoa, batez ere, gizarte-fenomenoen transbertsalitateak herrien autodeterminatzeko eskubidetik hiritarren erabakitzeko eskubiderako jauzia eman duen une historiko honetan. Arazo hau agerikoa da beren estatu edo errepublika independentea eraiki nahi duten Euskal Herriaren eta Kataluniaren kasuan. Hiritartasunak bere erroak estatuan ditu. Eta estatuak, bere lurralde-batasuna arriskuan ikusten duenean, nazio menperatuetan bi komunitateren arteko mamua pizten du. Ondorioetan, eraikitzear dagoen Euskal Herri independente batean, ezinbesteko oinarritzat jotzen dira, besteak beste, euskararen berreskurapena eta lurralde-batasuna. Eta, bide batez, estatu-nazioak krisian sartuta daudela eta askapen nazionalak goraka doazela gogoratzen da. Europan XX. mende hasieran 24 estatu ziren eta egun 50etik gora dira.

Gako-hitzak: nazioa, estatua, komunitatea, identitatea, herritasuna, hiritartasuna, populua.

«Nazio kultural euskaldunaren aurrerabideaz» gaiaren inguruan ikuspegi historikoa azaltzeko aukera izan nuen 2015eko urtarrilaren 15ean Mondragon Unibertsitateko Humanitate eta Hezkuntza Zientzien fakultateak (HUHEZIk) Eskoriatzan antolatutako mintegian. Aurrera baino lehen, esan dezadan, emana etorri zitzaigun izenburuan enuntziatuta datorrenez, nazio kultural hori nazio politikoari kontrajartzen zaiola, zeinaren arabera estatua baita nazio politikoa eraikitzen duena; nazio kulturala, aldiz, estatua lortu nahi duen proiektu politikoa izango litzateke. Lehen ereduan oinarritzen dira Frantziako Iraultzaz geroztik Europan eraikitako estatu moderno gehienak, funtsean plurinazionalak, Frantzia eta Espainiaren kasuan bezala; ${ }^{1}$ bigarrengoan, aldiz, estatu moderno zentralizatzaileak menpean hartu eta bere baitan irentsitako nazio etniko edo kulturalak, Euskal Herriaren kasuan bezala (Iztueta 2002: 110-112).

Hitzaldi hartan euskal foruak galduz geroztiko mugimendu politiko-kulturalak aztertu nituen, horietan guztietan euskal nortasuna zertan oinarritzen

\footnotetext{
1 Nielssonek $(1989,221)$ hiru estatu mota bereizten ditu: 1) estatu-nazioa, populazioaren ehuneko 90etik gorakoa nazio batekoa denean; 2) nazioa-estatua, populazioaren ehuneko 40-90 bitartekoa nazio batekoa denean; estatu multinazionalak, nazio nagusiaren populazioa ehuneko 40tik beherakoa denean.
} 
zen eta horren defentsarako zein bide eta zein xede markatzen ziren azalduz. Azkenaldion prentsan zein argitalpen akademikoetan argitaratuz datozen testu adierazgarrienak kontuan hartzen badira, ohartzen gara paradigmaaldaketa batzuen atarian gaudela. Demokrazia, hiritartasuna, transbertsalitatea, indibidualismoa, borondatea, subjektua eta antzeko kontzeptuak dira diskurtso berriaren zutabe oinarrizkoak. Nabaria da postmodernismoak egungo euskal intelligentsiaren baitan duen eragina.

Ondoren doazen lerrook ohar solte batzuk baino ez dira, eztabaidarako gogoeta-gai izan litezkeenak.

\section{Euskal Herria, euskararen herria}

Euskara maite dut. Nire hizkuntzetako bat da. Baina, argi diot, saiatuko naiz nire bizitza osoan gaztelaniaz hitz egiten eta nire ingeles kaxkarra perfekzionatzen. Eta, desio gisa, gustatuko litzaidake nire ondorengoek gaztelaniaz jakin dezaten, nik baino ingeles hobea hitz egin dezaten eta, frantsesa jakingo balute, bikain (bide batez, ongi legoke, behingoz, gure hezkuntza sistema gure herriko hizkuntzetako bat den frantsesaren irakaskuntzarekin zerbait planteatzen hasiko balitz). (Soto 2014)

Nolako euskal nazioa nahi dugu, euskaldun eleaniztuna ala erdaldun elebakarra? Euskal estatu independente batek bere hizkuntza nazionala euskara izango du ala euskara bezain ofizialak izango dira beste hizkuntza bertakotuak ere? Euskal gizartearen euskalduntzea biharko euskal estatu hipotetiko baten eskuetan utzi behar da, ala gaurdanik ekin behar zaio egiteko honi horretarako bitarteko errealak jarriz?

Egun euskal gizartean eleaniztasunaren aldeko apustu garbia egiten da, beste hainbat gauza bezala ezinbestez emana datorkigulako, baina ez da kontuan hartzen, gaztelera eta frantsesa euskal lurraldean hizkuntza nagusiak diren arren —eta gehiengo batentzat ama-hizkuntza ere bai-, bertako hizkuntza nazionala, izan, euskara dela eta horrek justifikatzen duela egun indarrean dagoen berreuskalduntze-prozesua, gerrate aurreko euskaltzaleek eta gerrate ondoko belaunaldi gazteek zalantzan jartzen ez zutena.

Hori esanda, galdera batzuk datozkit burura, orain arte planteatutakoetan funtsezkoenak zaizkidanak:

- Bat. Euskal naziotasunari dagokionez, ebidentzia osoz onartuz gero, Euskal Herriaren historia luzean zehar bertan egin diren hizkuntzak asko izan direla, egiaztapen horretatik abiatuz esan al daiteke guztiak, kasurako gaztelera eta frantsesa, maila berean bertakoak direla? Euskal tradizio osoan esana datorrenez, euskara ez al da Euskal Herria egiten duena? Beraz, bertako hizkuntza dena? Ez al du merezi deseuskal- 
dunduak izan ziren eskualdeak berreuskalduntzen ahalegintzea? Nahiz Euskal Herria euskaldundu, Bilbotik Tuterara, eta hemendik Baionara, lasai egon gaitezke bertako hizkuntza nagusiak desagertzeko arriskurik ez dagoela, euskal gizarteak eleaniztasuna izateari ez diola utziko.

- Bi. Etorkizuneko euskal estatua, inoiz lortzekotan ere, erdalduna ere izango dela? Hori, noski, geure esku dago neurri batean, euskaldunon eta euskaltzaleon eskuetan. Euskal estatu euskaldun bat irudikatzen ez dutenek, bertako zein kanpoko hizkuntzak euskara bezain garrantzitsutzat dauzkatenek, ez daukate zertan sobera kezkatu euskararen berreskurapen-prozesuak eman ditzakeen emaitzekin. Badut beldurra, euskara ofizializatuz gero ere, asimilazioak ere bere bidea egiten baitu -batez ere, ofiziala ez den eremuetan-, berreskurapen-prozesuak zango labur samarrak izango dituela, eta are laburragoak gizarte-ezarpenerako behar besteko botererik lortzen ez bada. Zentzu honetan, euskal estatuarekin nekez ikusten dut euskararen berreskurapena; eta gabe, berriz, ezinezkotzat daukat. Gehienez, orain bezala, malbiziko da. Beste arrazoi indartsuen artean, euskaltzaleak horregatik aldarrikatzen du euskal estatu baten beharra. Noski, eleaniztasun ahalik eta aberatsenaren barruan, nagusiki euskaraz biziko den Euskal Herri bat desiratzen dut. Erdal estatu batek izan lezakeen interesak ez nau erakartzen.

- Hiru. Estatu guztiek beren hizkuntza nazionala dute eta bertako hiritarrek hizkuntza hori badakite eta horretan mintzatzen dira. Eleaniztunak hiritar batzuk, gutxienak baino ez dira izaten gizarte gutxi-asko eleaniztunetan ere. Beraz, eleaniztasunak, dituen bere gizarte-abantaila guztiekin ere, bere mugak ditu, egungo mundu globalizatuan, non hizkuntzak gero eta gehiago nahasten eta gurutzatzen baitira, gutxiengo bat baizik ez baita eleaniztuna, bereziki goi-klase ilustratua.

- Lau. Izan liteke guztiz interesgarria ingelesa ondo menderatzea, bertako frantsesa eta gaztelera bezainbat ondo, baina zergatik ez, arrazoi beragatik edo antzekoagatik, alemana, txinera, edo besteren bat? Edo garai batean latina izan zen bezala hizkuntza ilustratua? Oroi oraino XIX. mendean Espainiako unibertsitatean latina zela nagusi.

Nolanahi ere, zorionez, ez dira belaunaldi honetako guztiak aburu berekoak. Badira euskara eta euskal estatua elkarri lotuak ikusten dituztenak: «Eta gaur egun oraino baldin bada euskal estatu baterako gogoa, euskal nortasunak iraun duelako da. Bistan da gainerako arloak lantzea funtsezkoa dela estatu bat sortzeko.» (Bidegain 2014: 3).

Garbi dago «euskal nazioa edo nortasuna», azken batean, hizkuntza eta kulturan oinarritzen dela.

- Bost. Euskararen ezagutza eta erabileraren arteko desoreka nabariaz jardutean, horren errua subjektu historikoren bati egotzi behar eta, erakundeetatik hiztun arruntari egozten zaio, euskaldunak zabarkeriaz edota errazkeriaz euskara ez den albo-hizkuntzetara jotzen duelako 
bere eguneroko bizitzan. Beraz, hiztuna, subjektu partikularra baizik ez dena, autoinkulpatua aurkitzen da. Ez bakarrik erakunde politikoen aldetik, baita euskararen egoeraz arduratzen diren hainbat adituren aldetik ere. Eta hala gertatzen da, hizkuntzari buruzko plantamenduak hiztunaren ikuspegirik begiratuta egiten direlako, hizkuntzarena arazo pribatu bat balitz bezala, hizkuntzen polisetik harago beste ezer ez balego bezala hartuz. Hala ote? Hizkuntza-komunitatea hiztunen batura baino zerbait gehiago ez ote da?

Diskurtso onargarria da hizkuntza-komunitatearen subjektuak, azken batean, hiztunak direla eta, euskaldunen komunitate hori minorizatua den aldetik, beraren sustapenerako barrutik eragin behar diola beraren erabilera eragiteko. Baina hori guztia neurri batean bakarrik liteke onargarria, hiztun bakoitzaren erabakimenetik harago baitago bere inguruko gizarte-egitura jakinek haren baitan eragiten duten hertsapenfaktorea. Eta honek, noski, zerikusi zuzena du botere hegemonikoarekin, klasearteko interesekin eta kanpoko zein barruko instituzioek zein alderdiek sustatutako hizkuntza-politikarekin. Koiuntura honetan zer egin dezake hizkuntza minorizatu batek — gure kasuan euskarak-, baldin bere oraina eta geroa hiztunaren esparrura mugatzen bada? Noski, elkarri eraginez dauden hizkuntzen dantzan, neurri politiko positiboak hartzen ez badira, minorizatua ez da sekula normalizatua izatera helduko.

- Sei. Eleaniztasuna egungo munduan fenomeno unibertsala dela esanda, badirudi dena esana dagoela. Gainera, eleaniztasunaren diskurtsoak plus baten bermea inplikatzen du egungo eskola-curriculumean, zeinaren arabera zenbat eta hizkuntza gehiago jakin eta erabili hainbat hobeto. Baina diskurtso honetan erdia baino gehiago falazia bat da, zeren ezagutzen ditugun estatu gehienen hizkuntza nazionalak mono-hizkuntzak baitira, ez eleaniztunak. Estatu bateko hiritar gehienak hizkuntza bakarrean eskolatzen dira, eta hizkuntza bakarra erabiltzen dute beren eguneroko harremanetan; gutxiengo bat baizik ez da eleaniztuna, bere eguneroko bizimoduan hizkuntza bat baino gehiago ezagutu eta erabiltzeko gai dena, normalean klase ilustratua. Laburki esanda: egun indarrean dauden estatuak, plurinazionalak diren kasuetan ere, elebakarrak dira bere lurralde osoan zehar. Autonomietako hizkuntza ofizialek eskubide pertsonala, pribatua, baizik ez dute; esparru publikoa, berriz, estatu-hizkuntza nazionalak hipotekatua dauka. Hizkuntzaren arazoa, funtsean, arazo politikoa da, publikoa, gizarteegituren mailan jokatzen dena eta ez, oso bigarren mailan ez bada, norberaren arazoa soilik.

Galdetu behar da behin eta berriz zergatik daukan euskaldunak berea ez den beste hizkuntza batean jarduteko ohitura. Nahi ez duelako? Ez. Bere unean uneko borondatetik harago, beste zerbaitek hartara eramaten duelako 
baizik. Pierre Bourdieuk ${ }^{2}$ (1979) habitus deitzen duen hori, sen hori, gure borondatetik harago garamatzan zer hori dago hizkuntza-portaera kontraesankor horren zolan, zeina, norberaren borondatea gaindituz, gizarte-egituretan oinarritzen baita; hots, lan-munduan, osasun-munduan, hezkuntza-sisteman, administrazioan, komunikabideetan.

Beraz, hizkuntzaren arazoa ez da euskaldunena bakarrik, baizik —eta batez ere-, hizkuntza-politikaren giltza duten gobernariena, politikariena.

\section{Euskal Herria, nazio etniko eta kulturala}

Nazio kulturala diogunean, historiaurretik gaurdaino Euskal Herri gisa ezagutzen dugun entitate soziologiko eta historiko hori dugu gogoan, egungo egoera administratibo eta juridiko zatitzailearen ondorioz Hegoaldea eta Iparraldea besarkatzen dituen horixe bera, zeinaren nortasun-zeinuak bere eskubide historikoetan, lurralde-batasunean, ekonomian, folklorean eta, batez ere, hizkuntzan gauzatzen baitira, eta zeinaren bilakabide historikoa herritarrek bere izateaz duten kontzientzia eta askatasunerako bidean garaian garaiko erresistentzian islatzen baita. Bi ezaugarri horiek, objektiboak eta subjektiboak, adierazten dute euskal nazio etniko edo kultural baten aurrean gaudela, non herritartasuna (naziotasuna) etnokraziarekin berdintzen baita, eta hiritartasuna (ciudadanía), aldiz, demokraziarekin. Tradizio klasikoan alde handia dago demokraziatik etnokraziara. Egungo mapa politikoan izaera kulturalik gabeko estatu-nazioek monopolizaturik daukate, ez bakarrik herritartasuna, baita hiritartasuna ere; hori batetik eta, bestetik, kontzeptu bi horiek era nahasgarrian erabiltzen dira. Horregatik, horien esanahia argitu beharra dago, eztabaidaren zelaia bere lekuan finka dezagun.

\subsection{Nazioa: etnikoa eta zibikoa}

Nazioaren kontzeptua XVIII. mendearen bigarren aldian sortu zen Helbezio (1715-1771), Voltaire (1694-1778) eta Herderrekin (1744-1803) eta XIX. mendean nazionalismoa garrantzi handiko gizarte-mugimendu bilakatu

\footnotetext{
${ }^{2}$ Habitusa autore honen baitan teoria soziologikoaren kontzeptu nagusietako bat da. Ekin, pentsatu eta sentitzeko modu bat adierazten du, norberaren egoera sozialari, itsatsita bezala, oturik doana. Horrek egiten du gizarte-inguru homogeneoa dutenek bizi-egoera antzekoa izatea (1979). Emile Durkheimek gizarte-egitateaz eskaintzen duen definizioak badu zerikusirik Pierre Bourdieuren habitusarekin: harentzat gizarte-egitateak «obratu, pentsatu eta sentitzeko moduak dira, gizabanakoari kanpokoak zaizkionak, eta hertsapenezko botere batez hornituak daudenak eta, ondorioz, ezarriak datozkionak» (1987: 36). Gizarte-egitate hauen ezaugarri nagusiak dira, batetik, kontzientzia indibidualetatik at existitzen direla eta, bestetik, gizabanakoengan hertsapenez eragiten dutela.
} 
zen. Nazionalismoa, ideologia gisa, autodeterminatzeko eskubideari atxikirik etorri izan da, Europako ekialdean bezala mendebaldean, zeinaren arabera herri edo nazio batek, halakotzat hartzen den heinean, bere etorkizuna estatu independente gisa aldarrikatzeko eskubidea baitu. Irizpide hori erabili zen Alemania, Italia eta Israelen bateratzea eta mundu zabaleko deskolonizatze-prozesuak egin zirenean. Estaturik gabeko nazioen kasuan, ordea, eskubide hori sistemaz ukatua izan da, eta kasu tipiko horretan sartzekoa da Euskal Herriarena, non bi estatu multinazionalen menpeko izateko patua gertatu baitzaio.

Nazionalismoaz eman izan diren azalpen teorikoak kasu gehienetan formula dikotomikoetan azalduta datozenak dira eta, zenbait puntutan, kontrajarriak ditugu. Horietako pare bat azalduko dut, zertan datozen bat eta zertan ez zehaztuz.

2.1.1. Hainbat autorek, hauen artean Tzvetan Todorovek (1985) eta Antonin Artaudek (1979), nazionalismo zibiko edo liberala nazionalismo etniko edo kulturalari kontrajarriz egiten dute nazionalismoari buruzko irakurketa.

Nazionalismo kulturalak —etnikoak-, nazio jakin baten eta bere obra historikoen kalitate espezifikoa baieztatzen du. Zehaztu behar da zeintzuk diren nazio horretako kideek dituzten ezaugarri komun horiek, belaunez belaun erreproduzitzen datozenak: erlijioa, arraza, mintzaira, izaera, ohiturak, zuzenbidea, folklorea, eta abar, lehen ere aipatuak. Nazio bateko partaide guztiek ezaugarri horiek partekatzen dituzten eta irudi ideal horrekin batera datozen heinean izango da norbait nazio bateko partaide. Ikuspegi honek etnizitatean du bere oinarria eta, zentzu honetan, nazionalitatea herentziazkoa da. Estatuari bere legezkotasun politikoa talde etniko batetik eratortzetik datorkio. Ikuspegi honek Herderren volk kontzeptuan du bere abiapuntua. Nazionalismo kulturalean, norberaren kulturarekiko atxikimendua nabarmentzen da, eta norberaren testuinguru partikularraren espezifikotasunean sakontzean, gune partikularretik unibertsalerako urratsa ematen da.

Nazionalismo politikoak —zibikoak-, ostera, komunitate politiko batekoa izatearekin du lotura, eta patriotismoarekin berdindu ohi da. Ikuspegi honen arabera, gorputz politiko horretako partaide diren gizabanakoek, batera bizitzeko borondatea agertzen duten heinean, gorpuz politiko horrekiko fideltasun-loturak sortzen dituzte. Adibidez, gertaera historiko jakin batzuk -hauen artean gerrak- batera izanak estutzen ditu lotura horiek. Nazionalismo mota hau hiritartasunean oinarritzen da. Askatasuna, tolerantzia, berdintasuna eta eskubide indibidualak gisako balio liberalak aldarrikatzen dituzten pentsalari politikoek sostengatzen dute nazionalismo mota hau. Autore hauen atzean, besteak beste, Renan eta John Stuart Mill daude. Kasu honetan estatuari bere legezkotasun politikoa populu edo hiritarren partehartze aktibotik datorkio, beti ere «herri-borondatea» ordezkatzen duen neu- 
rrian; hots, hiritartasunaren kontzeptua Jean Jacques Rousseauk gizarte-harremana definitzerakoan erabiltzen duen zentzuan ulertuta:

Beraz, baldin haren muinari ez dagokiona bazterrean uzten bada, ikusiko da gizarte paktua hitz hauetan biltzen dela: gutarik bakoitzak bere pertsona eta ahalmen guztia nahimen orokorraren gidaritza gorenaren pean elkargoan ematen du; eta, denek gorputz bat osatuz, kide bakoitza, osotasunaren ezin zatituzko parte gisa, errezibitzen dugu.

Elkartze horrek, ordutik beretik, hitzarmen egile bakoitzaren pertsona bereziaren ordez sorrarazten du gorputz moral eta kolektibo bat, biltzarreak boz duen bezainbat partaidez osatua, akta horretatik hartzen baitu honek bere batasuna, bere ni-tasun komuna, bere bizitza eta bere nahia. Pertsona guztien batasunak sorrarazten duen pertsona publikoari lehenago Zibitate zeritzan, eta orain Errepublika edo gorputz politikoa erraten zaio, haren partaideek Estatu erraten baitiote pasiboa delarik, Subirano aktibo delarik, Potentzia bere irudiekin erkatzen denean. Elkartekideek kolektiboki Populu izena hartzen dute, eta partikularki, aginpide subiranoko partaide gisa, hiritar deritze, bai eta Estatuaren legeen manupean diren aldetik meneko ere. Baina izen horiek maiz nahasten eta bata-bestearen ordez erabiltzen dira; aski da zuzenki enplegatzen direlarik bereiztea. (Rousseau 1762 [1993]: 45-46) ${ }^{3}$

Jean-Jacques Rousseauk inbokatzen duen populu edo zibitate hau ekintza moral bat da, zeinaren arabera moralitate hori ez baita gizabanako isolatu baten ekintza bat, populu batean batutako pertsonen elkarte bat baizik. Populua da bere buruari legea ematen diona. Eta populua subiranoa delako, horregatixe da lege-iturri. Gizarte-hitzarmenetik eratortzen den «borondate orokorra» da komunitate politikoa sortzen duena. Hiri-subiranotasun edo autoritatearen sorburua, beraz, ez datza naturan edo Jainkoagan, Aristotelesek edo San Tomasek uste izan zuten bezala.

J.-J. Rousseauk erabiltzen duen «peuple» kontzeptuan eta geroztik horretaz egiten den interpretazio politikoan datza eztabaida; geroxeago azalduko dugu.

3 «Chacun de nous met en commun sa personne et toute sa puissance sous la suprême direction de la volonté générale; et nous recevons en corps chaque membre comme partie indivisible du tout.

A l'instant, au lieu de la personne morale particulière de chaque contractant, cet acte d'association produit un corps moral et collectif composé d'autant de membres que l'assemblée a de voix, lequel reçoit de ce même acte son unité, son moi commun, sa vie et sa volonté. Cette personne publique, qui se forme ainsi par l'union de toutes les autres, prenait autrefois le nom de cité, et prend maintenant celui de république ou de corps politique, lequel est appelé par ses membres État quand il est passif, souverain quand il est actif, puissance en le comparant à ses semblables. À l'égard des associés, ils prennent collectivement le nom de peuple, et s'appellent en particulier citoyens, comme participant à l'autorité souveraine, et sujets, comme soumis aux Lois de l'État. Mais ces termes se confondent souvent et se prennent l'un pour l'autre ; il suffit de les savoir distinguer quand ils sont employés dans toute leur précision». (Rousseau 1762 [1978]: 164) 
Hasteko, haren populua subjektu moral bat da, errealitate historikoan inoiz existitu ez dena. Pentsamenduaren erresuman, hots, berori pentsatu zuenaren buruan bakarrik existitzen den izaki filosofiko bat da. Horregatik, populu honek ez dauka zerikusirik herri etnikoarekin, inguruan dauzkazun nire eta zure herri horiekin. Iraultzaile amerikarrek eta frantsesek, berdin autodeterminatzeko eskubidea errebindikatuz geroago etorri ziren mugimendu nazionalistek, populu unibertsala — berak le peuple deitua, artikuluarekin-, beren populu partikulartzat hartu zuten. Walker Connorrek (1989: 121) autodeterminatzeko eskubideaz eta nazionalitateen printzipioaz egiten duen irakurketa kritikoan, hain zuzen ere, ohartarazten du iraultzaile liberalek zein mugimendu nazionalistek populuari buruzko interpretazio desegokia eta okerra egin zutela:

Honek guztiak ez du esan nahi amerikar eta frantses iraultzaileak era kontzientean ari zirenik aldarrikatzen nazionalitateen beste hasiera bat. Uste zuten herri-subiranotasunari buruzko Locke eta Rousseauren ideiak praktikan jartzen ari zirela. Subiranotasunaren eta etnizitatearen arteko lotura, bi filosofoek aurreikusi gabea, agerikoegia zen iraultzaileek ere hautemateko. Ez ziren sortu, hamarkada batzuk beranduagora arte, askapen nazionalaren aldeko borrokak ugaritu ziren arte, «nazionalitateen hasiera» eta «nazioen autodeterminazioa» esapideak. Herrisubiranotasunaren nozioa aldatzen ari zirela jabetu gabe, ekintzaileek euren herria herriarekin ordezkatu zuten (...) Norberaren herria herriarekin berdintzeko joera horrekin batera, albaniar, euskaldun, bulgariar, katalan, kroaziar, txekiar, estoniar, finlandiar, greziar, galiziar, islandiar, irlandar, letoniar, lituaniar, hungariarrentzako edo beste nazio talde zehatz batzuentzako eskaera politikoen bidez adierazten zen Europan, gerra napoleonikoen eta Bigarren Mundu Gerraren artean, gobernatuen onespena zilegitasun politikoaren erabakitzaile nagusia delako nozioa. ${ }^{4}$

\footnotetext{
4 «Todo esto no quiere decir que los revolucionarios americanos y franceses estaban declarando de manera consciente un nuevo principio de las nacionalidades. Creían que estaban poniendo en práctica las ideas de Locke y Rousseau relativas a la soberanía popular. El vínculo entre soberanía y etnicidad, no previsto por estos dos filósofos, era muy obvio también para ser percibido por los revolucionarios. No fue hasta décadas más tarde, cuando el número de luchas por la liberación nacional aumentaron, que las expresiones 'el principio de las nacionalidades' y 'autodeterminación de las naciones' llegaría a acuñarse. Sin darse cuenta de que estaban modificando la noción de la soberanía popular, los activistas habían sustituido su pueblo particular por el pueblo (...) En consonancia con esta propensión a igualar el propio pueblo de uno con el pueblo, fue a través de las demandas políticas para los albaneses, vascos, búlgaros, catalanes, croatas, checos, estonianos [sic], finlandeses, griegos, gallegos, islandeses, irlandeses, letones, lituanos, húngaros, $\mathrm{u}$ otros grupos nacionales específicos, como la noción de que el consentimiento de los gobernados es el determinante principal de la legitimidad política se solía manifestar en Europa entre las guerras napoleónicas y la segunda guerra mundial». (Connor 1989: 121) [Bestelakorik adierazi ezean, itzulpenak egileak berak eginikoak dira. Hau Larraitz Zubeldiak egina da].
} 
Lerrakuntza horrekin, populu- $a$-artikuluarekin-, nire, zure herri bihurtzen da. Haren edukia horrela ulertzean, geroago ikusiko denez, Gemeinschaft aldarrikatzen dutenek ia bere osotasunean desjabetzen dute Gessellschat gizartearen oinarritzat jotzen zen hura (Connor 1989: 121).

Nazionalismo zibikoari egiten zaion kritiketako bat da herri jakin bat lehenetsi eta hautatzen dela beste guztien gainetik eta hori ekintza antiunibertsalista bat dela. Horrelako sententzia botatzen duena Tzvetan Todorov autorea da, 1939an Sofian jaio eta Parisen bizi izandako hizkuntzalari, filosofo eta historialaria, CNRSko irakasle eta zuzendaria. Honek L'expérience totalitaire: la signature humaine liburuan egungo estatu demokratikoen pentsamendu neokontserbadorea eta ultraliberalismoa zorrozki kritikatzen ditu, bere ustez, estalinismoak eta faxismoak eraiki zituzten ezaugarri berberak baitituzte. A. Artaud (1979: 203) oraindik harago doa Todorovek irekitako bide horretatik, dioenean «itxura egoista hartzen duenean, txaubinismoan jausten dela eta horrek aduanen arteko gatazkak eta gerra ekonomikoak dakartzala, erabateko gerrak ez esatearren». Europako estatu multinazionalak ez al dira izan mundu-maparen ia hiru laurdenak kolonizatuta eduki dituztenak? Ulertzen da Todorovek egungo estatu demokratikoez egiten duen kritika gupidagabea. Arriskua, zalantzarik gabe, nazionalismo kulturalaren etnozentrismoan baino askoz handiagoa dago nazionalismo politikoari darion usain neokontserbadore eta ultraliberalean, garai bateko totalitarismo eta faxismotik urrun ez dagoen korronte postmoderno horretan. Bi nazionalismo mota horien arteko bereizketarekin jarraitzea jokabide dogmatikoa dela ere idatzi da.

2.1.2. Ildo beretik jarraiki, bada nazioa eta nazionalismoari buruzko beste hurbilketa bat ere, etnokraziaren bidetik egiten dena eta, funtsean, jadanik aipatu dugun Tonniesek Gemeinschaft (komunitatea) eta Gesellschaft (gizartea) kontzeptuen artean egindako bereizketa jasotzen duena.

Arestian ikusi bezala, demokrazia liberaletan etnokraziak ez baitu lekurik, kontzeptu hori modan ez badago ere, saia gaitezen kontzeptu horren inguruko beste batzuk aipatu eta bereizten. Horretarako Zientzia Politikoetan aditua den Walker Connor aipatuak (1989: 111-130), Middebury College unibertsitateko irakasle denak, «Demokrazia, etnokrazia eta estatu multinazional modernoa: paradoxak eta tentsioak»(Democracia, etnocracia, y el estado multinacional moderno: paradojas y tensiones) gaiaz 1987an Gasteizen emandako hitzaldia ekarriko dut hona, haren ekarpena argigarri gerta dakigukeelakoan.

Hitzaldi honetan, nondik hasiko eta, Tonnies klasikoak Gemeinschaft eta Gesellschaft kontzeptuen artean egindako bereizketa azaltzetik hasten da. Politika-mundua antolatzeko bi printzipio arras desberdin gisa erabiltzen ditu.

Gizartearekin berdindu daitekeen Gesellschaften ereduak modu inpertsonalez osatutako elkarte pertsonalek ezaugarritzen duten eta modu arrazional 
eta mekaniko batez garatutako gizarte-harreman batean oinarritzen den gizarte bat deskribatzen du. Beren interesak gizarte horretako partaide izanez gero hobeto zaindu eta sustatuak izango direla uste duten gizabanakoek osatzen dute. Kontzeptu hau boluntarismo eta indibidualismoan oinarritzen da eta herri-subiranotasuna aurresuposatzen du. Gizabanakoaren balioa eta xedeak lehenesten dira. Arrazoimenaren produktu bat da.

Besterik da komunitatearekin berdintzen den Gemeinschaft kontzeptuaren edukia, zeina beren arbasoengandik datorkien tradizioa jaso eta bizitzen duten konbikzioa duten pertsonek osatua baita. Gizarte mota honetan balio-giltzarria duena talde etnikoa da eta taldearen ongizateari ematen zaio lehentasuna. Kontzeptu honen iturriak emoziozko eta intuiziozkoak dira, odol eta bihotzean dute beren jatorria. Kontzeptu honek, jatorriz, modernitate-aurreko Europako nekazari-gizarte tipikoa ezaugarritzen du, non pertsonen arteko loturak gehienbat ahaidetasunean eta zuzeneko harremanean oinarritzen baitira, herri txiki eta itxietan ohi den bezala. Horrelako herrietan bizi-arauak, kasurik gehienetan, adierazi gabekoak ziren eta gizabanakoak elkarrekiko mendekotasun-sare batez lotuak zeuden; beren bizitzako alderdi guztietan eragina zuten, familian bezala lanbidean.

Nahiz lehen gizarte mota horren erroak greziar demokrazian ezarri ziren, Klistenesen garaian, K.a. VI. mendean, ${ }^{5}$ Ilustrazioaren emaitzatzat hartu zen, praktikan orduan finkatu zelako maila politikoan. Honen sustatzaile nagusitzat Locke (1632-1702) eta Rousseau (1712-1778) aipatzen dira; eta horren adibide historiko nagusi gisa, berriz, Frantziako Iraultza eta Ameriketako Estatu Batuetakoa. Beste eredua, Gemeinschaftena, aldiz, berriagoa da. Gizarte politikoak eta talde etnikoak batera joan behar dutela dioen printzipioa XIX. mende hasieran landutakoa da, zeina gauzatzen baita lehenik nazionalitateen printzipioan eta gero nazioen autodeterminatzeko eskubidean.

Beraz, harreman dikotomikoak dituzte eta, oinarrian, kidetasunik badute lehen aipatutako nazionalismo zibiko eta etnikoarekin. Esan behar da gizarte edo komunitate politikoa antolatzeko bi modu hauek nekez gauzatzen direla beren egoera garbian errealitate politikoan. Biztanleriaren ehuneko laurogeita hamarretik gora talde etniko batekoak diren estatu demokratikoetan

\footnotetext{
5 Klistenes izan zen Atenas zaharrean gobernu demokratikoa ezarri zuena, aristokraziaren boterea murriztuz eta herriarena zabalduz. Legearen aurrean hiritar guztien berdintasuna aldarrikatzen duen estatu berri honi isonomia deitu zion, ez demokrazia, hots, herriaren gobernua. Berrikuntza hauen aurretik, Atenas odolezko harremanez elkartutako lau tributan antolatua zegoen. Klistenesek batasun hori 10 tributan berrantolatu zuen modu artifizial batez eratutako Atikako eskualde geografikoetan banatuz; hots, mendialdean, kostaldean eta hirigunean. Zeharkako ereduan eraikitako gobernu-sistema bat zen, zeinaren helburua baitzen atenastarrak beren buruak poliseko hiritar moduan ikusi eta sentitzea eta ez, ordura arte bezala, familietako eta eskualde jakin batzuetako partaide moduan. Demos honek ez du, bada, zerikusirik zentzu etnikoan ulertutako herriarekin.
} 
eta, beraz, Gemeinschaften sailkapena aplika daitekeen kasuetan (adibidez, Austria, Norvegia, Danimarka, Finlandia, Austria Federala, Islandia, Irlanda, Portugal edo Suedian, Katalunian edo Euskal Herrian), kargu politikoetarako hautatuek beren egitarauak aurkezten dituztenean, nahitaez beren xede indibidualetara jotzen dute, xedeok gogoan dituztelarik: bizi-maila garaiago bat, hezkuntza-hobekuntzak, garraiobide hobeak, eta abar. Hau guztia egia bada ere, horrek ez du baliogabetzen aipatu bereizketa hori. Zeren egiazkoa baita bi gizarte mota horien arteko bereizketa, zeinaren arabera beren estatua errebindikatzen duten nazio gehienak etnikoak baitira eta indarrean dauden estatuak, aldiz, estatu-nazioak, nazio-estatuak eta estatu multinazionalak dira; besteen artean, Erresuma Batua, Belgika eta guri zuzenean dagozkigun Frantzia eta Espainia (Nielsson 1989: 215 ). Azken hauen legitimitate politikoa Gesellschaften oinarritzen da. Baita hortik ondorioztatzen den hiritartasuna ere, gure kasuan gertatzen den bezala. Beraz, gaur egun subiranotasunaren subjektua hiritar guztien borondate indibidualean oinarritzen denean, jakin behar da demokraziaren izenean aldarrikatzen den hiritartasun hori estatu multinazionalari atxikirik doan atributu bat dela. Izan ere, gizarte mota horietako bakoitzak du bere legitimitate politikoa, eta bietan bermatzen dira hiritarren eskubide indibidualak. Estatu bakoitzak du bere konstituzioa, eta hor finkatzen dira manupeko populazio zibikoa bermatzen duten legeak, hiri-demokraziaren adierazleak, behar izanez gero bortxa sinbolikotik harago fisikoa baliatzea baimentzen dutenak. Nazio menperatuetan estatuko erakundeek demokrazia sustatzen dute, hiritar subiranotasuna ere bai; ez, ordea, independentziaren aldarria.

Geroztik komunitateaz eman diren definizioetan oinarrizko bi elementu hauek aipatzen dira: 1) estrukturalak, non komunitatea erakunde politiko eta sozioekonomikoek gobernatzen duten eta eremu geografiko jakin batean kokatuta dagoen talde gisa hartzen baita; izan dadila auzo bat, hiri bat, nazio bat edo nazio-talde bat; 2) funtzionalak, batez ere komunitatearen behar objektiboak eta interes komunak kontuan hartzen dituztenak dira, beren eragina alderdi sozial eta psikologikoetan dutenak (Arias 2003: 28). Beste batzuek komunitatea, kokapen geografikotik harago joanez, zentzu zabalago batean ulertzen dute, hor sartuz historia komuna, interes partekatuak, errealitate espirituala, ohiturak, azturak, arauak, sinboloak eta kodigoak batera dituztenak (Socarras 2004: 177).

2.1.3. Gurean, nazionalismo etniko eta zibikoen ezaugarriez jardutean, lehena «herentziazkoa» eta bigarrena «borondatezkoa» dela esan da. Jose Luis Orella irakaslearen ustez, ez bata eta ez bestea. Aberria —irakur herria-, hautatu egiten da, baina betiere bere historiatik aldez aurretik emanak datozkion baldintza objektibo batzuen gainean:

Aberria ez da heredatzen, ezta ezartzen ere, hautatzen baizik. Izadia, herentzia, paisaia eta ingurua dira geroko abertzaleak moldatzen dituz- 
ten aberria hautatu aurreko baldintzak. Ama-hizkuntza propioa edota erabiltzen dituen hizkuntzak, hiritarrek kontatu dioten historia eta nazionalismo horretako partaideetako bakoitzak bizi izan duena eta hartu izan duen heziketa dira haren umotzearen osatzaileak. Azkenean, eta nagusiki, aberriaren aukera norberak egiten duen askatasun eta maitasunaren ariketaren emaitza da. ${ }^{6}$ (Orella 2014).

Haren ustez, berezko gizarte horiek, aberri edo nazio horiek, beren eskubideak dituzte nahi dutena izateko, nahi izanez gero, baita estatu independente bilakatzeko ere.

Aurre-ohar hauek eginda, gatozen etnokrazia eta demokrazia elkarri nola lotuta dauden azaltzera.

\subsection{Ethnosa ala demosa, ala biak?}

Ethnosa (identitate kulturala, nazio kulturala, hizkuntza...) eta demosa (identitate politikoa, erabakimena, estatua...) bateragarriak al dira estatu plurinazionalen baitan? Salbuespenak badaude, baina oro har ez dira ondo ezkontzen bi osagai horiek estatu multinazionalaren egitura politikoan. Zehaztasun batekin, hala ere, zapalduetan etsaitasuna dago ethnosaren (nazio minorizatuaren identitatea) eta demosaren (estatu mailako erabakimena) artean. (Odriozola 2017: 23)

Arazoa sakonekoa dela ezin uka. Etnokraziaren kontzeptua aspaldion erabat baztertua baitago, desgaraian gatozela badirudi ere, gatozen aztertzera.

\subsubsection{Ethnosa: Herri-subiranotasunaren iturri}

Etimologiari dagokionez, etnokrazia grekozko hitz elkartu bat da (etnos = herri, eta kratos = boterea), eta herriaren kontzeptua kasu honetan nazioarekin berdintzen da, zeinetan nazio-komunitate horretan partaide direnek batera baitituzte praktika kultural, linguistiko, politiko eta ohitura batzuk, mendez mende gordetzen dituztenak. Etniaren kontzeptua batzuetan arrazarekin edota gutxiengo talde jakin batekin berdindu izan da eta, ondorioz, estatu-nazioek sistemaz diskriminatu izan dituzte, berez eta izaeraz komunitate politiko ez-demokratikotzat hartuz. Horrela jokatzean, noski, etniari zentzu negatiboa ematen zaio, jatorrizkotik urrunduz, zeinaren arabera kontzeptu

\footnotetext{
6 «La patria no se hereda, ni te la imponen, sino que se elige. Los condicionamientos previos a la elección de la patria son la naturaleza, la herencia, el paisaje y el ambiente que acuna a los futuros patriotas. Los integrantes de su maduración son la lengua propia que se mama y la lengua o lenguas en las que se expresa, la asunción de la historia que los conciudadanos le han contado y que cada uno de los miembros de ese nacionalismo ha vivido y la formación que ha recibido. Y final y principalmente, la elección de la patria es el resultado del ejercicio de la propia libertad y del amor. Se elige lo que se ama y se ama lo que se elige.» (Orella 2014)
} 
horrek ezaugarri bereziz hornitutako herri-nortasuna edo herritartasuna islatzen baitu, nagusiki hizkuntzan oinarritzen dena. Etnonazionalismoa zentzu horretan ulertuta, euskal nazionalismoak berreskuratu beharreko kontzeptu bat da, bera baita, unean uneko borondatea eta kontzientzia gisako elementu subjektiboez gain, idearium edo proiektu politiko horri oinarri objektiboa ematen diona.

Etnokrazia, egin ohi den irakurketa ohikoan, gobernatzeko modu bat gisa hartzen da, gizarte politikoa antolatzeko modu bat gisa, non demosen gainetik lehentasuna ematen baitzaio etniari. Etnokraziak etnonazionalismo edo nazionalismo etnikoaren ondorio eta helburutzat hartuak izan dira, eta kontzeptu horren kontrakarrean mugatu izan dira, batetik, demokrazia etnikoak, zeinetan aintzat hartzen baita herriek beren buruaz erabakitzeko duten oinarrizko eskubidea, eta, bestetik, demokrazia liberalak, zeinetan zuzenbidezko estatuak beretzat gordetzen baitu bere menpeko herrien oinarrizko eskubide hori. Zuzenbidezko estatu multinazional gehienetan, errebindikazio etnokratikoak -irakur nazionalistak - berez antidemokratikoak bailiran hartuak izan dira; adibidez, Hegoaldeko Afrika, Belgika, Estonia eta Letonia, Israel, Malaysia, Serbia, Ugandan eta.

Gurean, euskal nazionalismoaren edukia azaltzerakoan, Federiko Krutwigek landu eta erabili zuen kontzeptu hori, lehenik luze Vasconia liburuan (1962: 31-110) eta geroxeago Manifiesto por la Etnocracia lanean (1964). Noski, gaur egun, etnosetik eratorritako kontzeptu politiko guztiak — hala nola, etnokrazia eta etnonazionalismoa - baztertuak bezala daude. Max Weberrek kontzeptu nahasgarria zela esan zuenez geroztik, kontzeptu madarikatua da eta badira, besterik gabe, nazismoarekin berdindu dutenak ere. Nahasgarria izateaz gain, «perennialitate»aren edo «primordialitate»aren atributua ere egozten zaio, esentzia bat bailitzan hartuz. Horrela gogo emanez gero, noski, zaila da nazionalismo etnikoaren erreprodukzioaz zentzu dinamikoan jardutea.

Etnizitatea zentzu estatikoan ulertzeko arriskua baldin badago ere, ukaezina da, bestalde, «iraunkortasun» etnikoa egiazko gizarte-fenomeno bat dela, Euskal Herriaren kasuan bezala, iraupen luzeko fenomeno historikoetan egiazta daitekeena. Jose Ignazio Ruiz Olabuenaga soziologoak (1989: 134), adibidez, euskal mugimendu etnikoak jadanik XVI. mendetik aurrera dokumentatuak daudela sostengatzen du, tradizio horretan sartuz Juan Perotxegi, Manuel Larramendi, Sabino Arana eta abarren mugimenduak. Bost mende luzez bederen erreproduzituz etorri da nazionalismo etnikoa.

Azken orduko postmodernismo neoliberalaren beroan hanpatu den indibidualismoak eraikitako diskurtsoa nagusitzen da edozein motatako errebindikazio kolektiboetan. Badirudi eskubide indibidualak eta kolektiboak bateraezinak direla. Ahaztu egiten da historian zehar planteatu diren errebindikazioak eta gauzatu diren konkista sozial nagusiak, erreformak zein 
iraultzak talde kolektiboek gauzatuak izan direla. Horregatik, ez dugu uste arazoak sinplifikatzearekin konponbidean asko aurreratuko dugunik.

Etnokrazia herri-erresistentziaren emaitza historikoa da. Estatu multinazional askok nahita aplikatu zuten asimilazio-politika, horien artean Frantziak eta Espainiak, eta horien kontrako erresistentzian agertzen dira etnonazionalismoaren isla diren etnokraziak, Euskal Herrian bezala Bretainia eta Korsikan, batez ere Bigarren Mundu Gerraren aurretik etnien arteko harremanak estutzen hasi zirenean.

Herri-subiranotasunaren edukia da dioena goi-aginte politikoa herrian edo etnian eta, beraz, gobernatuen onarpenean datzala, bera dela legitimitate politikoaren baliozko oinarri bakarra. Hauxe zen autodeterminatzeko eskubidearen aurrebaldintza. Masak dira, azken batean, aginte politikoaren iturri. Gertatu izan dena da, egun ere bai neurri batean, herri-subiranotasunaren printzipioa errealitate praktikoan aplikatzean, estatuek konstituzioan ezarritako legeriarekin nahastu izan dela eta, ondorioz, herrien nortasuna, kolektibo etniko oso baten ahotsa, sistemaz baztertua eta zapaldua izan dela.

Gemeinschafta historian zehar gauzatu den gizarte-fenomeno bat izanda, galdetzen da ea herri-subiranotasunari zein autodeterminatzeko eskubideari buruzko arrazoibideak zergatik ez diren izan aipatuak orain gutxi arte.

Independentziaren aldarrikapena herri-subiranotasunari loturik dator. Ez nahitaez, antolaketa autonomiko, federal edo konfederal batekin konforma daiteke, baina bere azken helburua estatu independentea lortzea da.

Independentziaren aitzindaritzat Agustin Xaho aipatu izan da, «Zazpiak bat» lelopean, Euskal Errepublika independentea aldarrikatu zuelako 1848an, justu Marx eta Engelsek beren Manifestu Komunista idatzi zuten urte berean. Bere aurretik, ordea, urrats hori emana zuen Manuel Larramendik bere Sobre los fueros de Guipúzcoa lanean (1766-68). Obra hau hiru mendez zentsuratuta egon zen eta 1983. urtean argitaratu zuen Telletxea Idigorasek. Liburu horretan planteatzen du Larramendik independentziaren aukera, foruak arriskuan zeudelako edo, horien alde arrazoituz. Andoaindarrarentzat foruak, pribilegioak ez, baizik euskal probintzien independentzia eta autonomiaren oinarri ziren, hots, eskubide lortu eta hitzartuak, eta horien defentsarako bortxa erabiltzea ere ontzat ematen du. Aterabide gisa euskal lurralde guztiak batuta egongo liratekeen Pirinioetako Probintzia Bateratuak, Euskal Errepublika independente bat, eraikitzea proposatzen du:

Zein arrazoi ematen da euskal nazioa, Espainiako lehen herria (...), bere jatorria ezin nobleagoa duen nazio hori, nazio bereizi bat izan ez dadin, berezko nazio bat, nazio askea eta besteengandik independentea?

Pirinioetako Probintzia unitateen proiektua benetan handia eta zoragaria da. Bere gobernu aristokratiko edo demokratikoarekin, ondoen 
letorkeenarekin, famatua izango den Errepublika. (Larramendi 1766-68 $[1983])^{7}$

Manuel Larramendik, gogoeta horiek egitean, Hegoaldean zein Iparraldean foruak behin betiko galtzeko arriskua zeukan gogoan. Estatu espainolak 1746ko urtarrilaren 16an aldarrikatutako Nueva Planta dekretuaren ondorioz, Valentzia eta Mallorcako erresumak eta Kataluniako Printzerria beretu zituen; handik ez luza, Konbentzioak, orobat, 1790ean Lapurdi, Nafarroa Beherea eta Zuberoako foruak baliogabetu zituen. Motiboak zeuzkan, eta zeuden, pentsatzeko antzeko zerbait gerta zitekeela euskal foruekin ere.

Sabino Aranak Euskadi nazioaren inguruan egiten duen independentziaren aldarriak zerikusi zuzena du, hain zuzen, euskal foruen abolizioarekin. Xaho eta Larramendiren tradizioari jarraiki, beste eduki garrantzitsu bat eransten dio independentziari, eta da xede nagusi horri buruz gizarte-mugimendu berri bat sortuko dela. EAJ izan zen bere aldarrikapen formalari eduki soziala emango ziona EAJ historikoaren sorrerarekin. Honek eman zion hasiera euskal nazionalismoari. Eta hor bere meritua du, berari zor zaiona.

\subsubsection{Demosa: Hiri-subiranotasuna}

Demokrazia, etimologiari dagokionez, etnokrazia bezala, grekozko hitz elkartu bat da $($ demos $=$ populua eta $k r a t o s=$ boterea $)$, eta estatua antolatzeko era bat gisa ikusia da historian zehar. Grezia klasikoan, lehen esan denez, Klistenes izan zen gobernu demokratiko baten zutabeak ezartzen lehena. Ondoko mendeetan, lehenik Platonek eta gero Aristotelesek gobernatzeko hiru mota bereizi zituzten: monarkia, edo baten gobernua; aristokrazia, edo onenen gobernua (Platonentzat), edo gutxienen gobernua (Aristotelesentzat); demokrazia, edo askoren gobernua. Gobernua horrela sailtzeko irizpidea, funtsean, gizarteko klase sozialetan eraikitzen da. Garai hartako greziar gizartean, geomoroak (nekazariak), demiurgoak (artisauak) eta eupatridak (nobleak) zeuden. Horiez gain, metekoak (Greziako polis edo hirietako batean bizi zirenak, baina hiritar titulua ez zutenak), esklaboak eta emaztekiak ere bazeuden, baina hauek ez ziren demosean sartzen, ez zuten Greziako hiritar titulurik. Horiek ziren garai hartako greziar gizartean zeuden klase sozialak.

Alabaina, demokraziaren kontzeptua denboran zehar aldatuz etorriko da, batez ere XVIII. mendean sistema demokratikoetan bozkatzeko eskubide

7 «Qué razón hay para que la nación vascongada, la primitiva pobladora de España (...) esta nación privilegiada y del más noble origen, no sea nación aparte, nación de por sí, nación exenta e independiente de las demás?».

«El proyecto de las Provincias unidades del Pirineo es sin duda magnífico y especioso (hermoso). República que se hará famosa con su gobierno aristocrático o democrático, como mejor pareciese. (Larramendi 1766-68 [1983]) 
unibertsala onartu zenez geroztik, eta emakumeen bozkatzeko eskubidea xx. mendean. Baina, nazio-arazoari dagokionez, aplikazio konkretuetara etorrita, demokrazia liberaletan, bere bertsio guztietan, ez dira onartuak izan nazio menperatuen eskubideak, ezta demokrazia sobietarrean ere, nahiz eta sobieten 1917 ko konstituzioan onartzen den autodeterminatzeko eskubidea. Alabaina, praktikan, herrialde kolonialetan aplikatuko da; horietan sistemaz. Autodeterminatzeko eskubideaz edo erabakitzekoaz, azken hamarkada hauetan bakarrik ezagutu dira salbuespen batzuk Europako Ekialdean bezala Mendebaldean. Arazoa ez datza nazioarteko zuzenbidean herrien eskubide kolektiboak - horien artean autoderminatzekoa - aitortzen diren ala ez maila juridikoan eztabaidatzen jarraitzea, baizik eta egiaztatzea, praktika politikoan, estatuek ez dutela jasotzen oinarrizko eskubide hori beren konstituzioetan. Estatuek beren demosa inposatzen dute beren menpeko nazio-errebindikazio guztien gainetik. Printzipioz demosek eta ethnosek bateragarriak izan beharko lukete, baina praktikan ez da horrela gertatzen. Estatu multinazionalek ez dituzte behar besteko baldintzak betetzen demokratikoak izateko.

Demokraziak herri-subiranotasuna aurresuposatzen du, hots, etnokrazia, baina ez alderantziz; era berean, etnokraziak ez du aurresuposatzen independentzia, baina bai, gutxienik, autonomia esanguratsua (Connor 1989: 126). Honela, bada, autodeterminazioa demokratikoa izango da bere atxikimendu politikoak hautatzeko orduan nazio-talde orori datxekion eskubide kolektiboa aurresuposatzen duen kasuan, orduan bakarrik, baina horrek ez du aurresuposatzen nazio-talde horrek zein gobernu mota hartu behar duen. Beraz, oinarri-oinarrian dagoen kontzeptua etnokraziarena da, nazionalismo konstituzionalista eta unionistan babesten diren politikari profesionalek eta politologo akademikoek bazterrean utzita daukatena.

Teorian, bi printzipio horiek, etnokrazia eta demokraziak, osagarriak izan beharko lukete. Baina, praktikan, kasurik gehienetan ez da horrela gertatzen $\operatorname{ari}^{8}$. Urrutira joan gabe berrikitan Katalunian gertatzen den bezala:

Bi osagai horiek ez dira izan bateragarriak Kataluniaren nazio askapenean: beraz, demosa versus ethnosa.

Urliak (espainiarrak) sandiaren (katalanaren) nazio proiektuan esku hartzeko eskubidea ematen omen die beren Konstituzioak. Hori omen da

\footnotetext{
8 Diogunaren adibiderik garbienetako bat Podemosek nazio-arazoari buruz duen jokabidea izan liteke: eskubide demokratiko bat den aldetik, ezin da ez onartu autodeterminatzeko eskubidea, baina eskubide hori praktikara eramateko orduan, independentziaren kontrako jokabidea agertuko du. Hau Leninen bertsio berritua da, marxismo klasikoak SESBn eta kolonia-herrialdeetan aplikatu izan duena eta erakunde estatalek —eta horien artean Podemosek-, sistemaz Katalunian zein Euskal Herrian aplikatzen datozena. Horientzat guztientzat Espainia da «nazioen nazioa», «Patria» handia.
} 
demokrazia eta legearekiko leialtasuna. Hortaz, Espainiak kontrolatzen duen estatu plurinazionalaren barruan espainiar bat katalan edo euskaldun bat baino gehiago; gehiago, ez bakarrik zentzu kuantitatiboan, kualitatiboan ere bai. Espainolak erabat naturalizatua dauka bere gehiagotasuna, bere nagusitasuna, bere arrazismo kulturala; izan ere, bere nazioan (Espainian) ez ezik, Kataluniako edo Hego Euskal Herriko nazio arazoan berak zer esana dauka; katalan edo euskaldunak, aldiz, bere nazio propioaren etorkizuna ere ezin du bere kabuz erabaki. Eta hori demokraziaren izenean egiten duela esango digu Espainiak, egiten dutela esango digute espainolek; alegia, gehiengoaren izenean. Horrela funtzionatzen du hitzetik hortzera darabilgun «demokraziak» estatu plurinazionalean; etnozidioaren logikan, alegia. (Odriozola 2017: 23)

Ez da harritzekoa hala gertatzea. Izan ere, bere sistema politiko demokratikoa Gesellschaften ereduan oinarrituta daukan estatu multinazional batek bere menpeko nazio etnikoak sistemaz ukatzen dituenean, hots, menpeko nazioen autodeterminatzeko eskubidea onartzen ez duenean, demokrazia hori lotsagarri eta hipokrita bilakatzen da, sasikoa. Kontzeptu hutsa da, estatu neoliberalak bere interesen neurrira, nahierara erabiltzen duena, herritarren zein hiritarren eskubideak sistemaz zanpatzen dituena.

\section{Subiranotasun-subjektua}

Intelligentsia akademikoaren baitan ahots berriak agertuz datoz esanez oraindik gaur egun indarrean dauden estatu-nazioak xxi. mendeko egoera politiko berrira moldatu beharrean aurkitzen direla. Espainian bertan 1978ko konstituzioa eraberritu beharra aldarrikatzen dutenak gero eta gehiago dira, ez gutxi nazio minorizatuen askapen-errebindikazioek eraginda, «café para todos» errezeta autonomikoa aspalditxo gainditutzat emana dagoelako.

Hasteko, nazionalismo etniko eta zibikoaren arteko antitesia gainditutzat ematen da:

Nazionalismo zibikoaren (balio jakin batzuei atxikitzen zaionaren) eta nazionalismo etnikoaren (partaideek bizia eta borondatezkoa den komunitate kolektibo batetik abiatuta eraikitzen duten berezko entitate gisa definitzen den nazioaren) arteko banaketa manikeoa beti izan zen errealitatearen deskribapen konbentzigarri bat baino gehiago, dikotomia teoriko bat. (Sanz Moreno 2017: 56)

\footnotetext{
9 «La separación maniquea entre nacionalismo cívico (adhesión a determinados valores) y nacionalismo étnico (definición de la nación como entidad natural que se construye desde la inserción de sus miembros dentro de una comunidad colectiva, viva y volitiva), siempre fue más una dicotomía teórica que una convincente descripción de la realidad.» (Sanz Moreno 2017: 56)
} 
Norabide berean doa beste pasarte hau ere:

Ez dago nazionalismo zibiko/etniko bereizketarako arrazoirik, eredu binario (eta manikeo) hori baztertu beharra dago, baldin eta orain arte nagusitu diren diskurtso politikoen arabera ulertuko badugu bederen. (Zubiaga 2014c)

Aurrera begira, aldaketaren paradigma gisa, hiritartasuna ezartzen da:

Orainari dagokionez, hiritartasuna begirada guztien erdigunean dagoela nabarmenduko dugu: xx. mendeko desbideratzeek, beren odolezko eta lurraldezko aliantzarekin, ezinezkoa egiten dute nazionalismo etnikoagoarekin haustea eta balio zibikoetan oinarritutako nazionalismo bat berrosatzea. Hemendik dator hiritartasuna berrosatzeko proposamenek arbuiatu egiten dutela nazio biologikoko haitzulora itzultzea. Baina, geroari begira, galdetu behar dugu ea guztiak barne hartuko dituen eta guztien parte-hartze politikoa bilatu duen demokrazia-eredu baten bila aurrera egiteko gauza garen. (Sanz Moreno 2017: 53) ${ }^{10}$

Espainian zabaltzen ari den demokrazia berrituaren irudi hori bere bidea egiten ari da ezker abertzalean ere. Aldaketa, ez oinarrizko kontzeptuetan, baizik azken helburua lortzeko prozesu eta planteamenduetan ematen da. Proposatzen den bidea izango litzateke, ondorengo aipuan datorrenez, hiritartasunean sakondu eta, gizarte-sareak indartuz, eskabide nazionalak eta subiranistak prozesu berean uztartzea eta, ondorioz, indar-metaketa hori lehenestea. Hortik doaz EHUko irakasle batzuen burutazioak. Mario Zubiagak honela dio «¿Queremos?» artikuluan (Gara, 2014-06-15):

Borroka sozio-politiko garaikidea eremu guztietan erabakitzeko gaitasunaren inguruan dabil (...) Horregatik, hiritartasunak, defentsarik gabekoak eta sinesgabekoak, bere bizitza pribatu eta publikoari eragiten dioten erabakien gaineko kontrola berreskuratu nahi du (...) Kontsumoaskatasuna estatuen nazio subiranotasuna berreskuratzearekin, edo nazioen estatu subiranotasuna lortzearekin, lotzen da. Horregatik, eskaera subiranistak ez daude prozesu honetatik kanpo. Badirudi aldatzen ari dena, katalan prozesuak erakusten duen bezala, gizarte-eskaera planteatzeko modua dela. Kontzeptu handiak - nazioa, subiranotasuna, lurraldetasuna-, ez dira zokoratzen, jokoan dagoena ez baita aldatzen (...)

\footnotetext{
10 «Respecto al presente, destacaremos cómo la ciudadanía se convierte en el centro de todas las miradas: los desvaríos del siglo xx con su alianza de sangre y tierra hacen imprescindible romper con el nacionalismo más étnico y recomponer un nacionalismo de valores cívicos. De ahí que las propuestas de reconstrucción de la ciudadanía rechacen la vuelta a la caverna de nación biológica. Pero, para proyectarnos hacia el futuro, debemos preguntarnos si podemos avanzar hacia un modelo de democracia que permita la inclusión de todos y la búsqueda de su participación política.» (Sanz Moreno 2017: 53)
} 
Halere, horietara iristeko era desberdina da, zertaz erabaki kontuan hartzen bada, nire gorputzaz, energia- edo hezkuntza-ereduaz. Edo nire elikaduraz (...) erabaki nahi dut norekin konpartitu nahi dudan proiektu politiko bat, alde batera utzita komunitate subiranoa osatzen dugun pertsonen nazio-nortasuna, hizkuntza edo ideologia (...) Autodeterminazioa modernizatu egin da. ${ }^{11}$

Egile honek berak, «Zeitgeist» artikuluan (Gara, 2014-10-11), hiritarren erabakitzeko eskubidea zuzeneko demokrazian gauzatzen dela esaten du:

Hiritarrek botere esparru guztietan duten erabakitzeko askatasunak, egunerokotik hasi eta estatalitatearen inguruko aukera kolektibora arte luzatzen denak, zuzeneko demokraziaren berkontzeptualizazioari ematen dio bide. ${ }^{12}$

Subiranotasunaren subjektua, bada, herria dela esango du, baina behar adina zehaztu gabe zein den horren edukia:

Subiranotasunaren subjektua ezin da izan herria baino. Subjektu kolektibo bat da, etengabe eraikiz eta identifikatuz doana eskaeren artikulazio ezegonkorren bidez, eta nazio-identitate finkoak ordezkatzen dituena. Erabaki nahi izatea da eraikitzen doana, subjektu kolektiboak konpartitzen duen substratu kultural baten gainean. «Nazio» hitza, jadanik baden komunitate objektibo gisa ulertuta, desegokia da, eta areago oraindik, «euskal nazionalisten» autoidentifikazioa baztertzeko arrazoia da, menpeko kategoria bat delako, soilki funtzionatzen duena onarpena kanpoko politikaren eremuan gauzatzen denean. (Zubiaga 2014b) ${ }^{13}$

11 «La lucha social y política contemporánea gira cada vez más en torno a la capacidad de decidir en todos los ámbitos (...) Por eso, la ciudadanía, inerme y descreída, busca recuperar el control sobre las decisiones que afectan a su vida privada y pública (...) Se conecta la libertad de consumo con la recuperación de la soberanía nacional de los estados, o la consecución de la soberanía estatal de las naciones. Por eso, las demandas soberanistas no están al margen de este proceso. Lo que parece estar cambiando, tal como enseña el proceso catalán, es el modo de plantear la demanda social. No se arrumban los grandes conceptos — nación, soberanía, territorialidad—, porque lo que está en juego no se cambia (...) Sin embargo, la forma de llegar a los mismos es distinta del mismo que quiero decidir sobre mi cuerpo, sobre el modelo energético o educativo. $\mathrm{O}$ sobre mi alimentación (...) quiero decidir con quién quiero compartir un proyecto político, independientemente de la identidad nacional, lengua o ideología de las personas que formamos una comunidad soberana (...) La autodeterminación se moderniza.» (Zubiaga 2014a)

12 «a liberación de la decisión ciudadana en todos los ámbitos de poder, desde el más cotidiano a la gran opción colectiva en torno a la estatalidad, abre paso a una reconceptualización de la democracia directa.» (Zubiaga 2014b)

13 «El sujeto de esa soberanía no puede ser sino el pueblo. Un sujeto colectivo que se construye e identifica continuamente por medio de la articulación inestable de las demandas, y que sustituye a las identidades nacionales fijas. Es el deseo y el hecho de (querer) decidir el que va construyendo, sobre un substrato cultural compartido el sujeto colectivo. Es el sentido de la inconveniencia del término 'nación', entendido como comunidad objetiva preexistente y, aún 
Francisco Letamendiak ere, «Soberanía permanente y derecho a decidir» artikuluan (Gara, 2014-11-11), antzeko arrazoibideak agertuz, gainditutzat ematen du nazio-arazoari buruzko diskurtso etnikoa, kontrakarrean erabakitzeko eskubidea erakunde transbertsaletan oinarritzen diren hiritar guztien eskuetan utziz:

Gobernu espainolek adiskidetze- eta baketze-prozesurako izan duten etsaitasunezko itxikeriak, halere, subiranistak ez diren euskal segmentuetara heltzeko bide bat irekitzen du: demokraziarena da hori. Erakunde zeharkakoek eta, Gure Esku Dago gisa, ez aldekoek aldarrikatzen duten erabakitzeko eskubidearen diskurtsoa, batez ere, demokratikoa da: subiranotasuna kolektibo orok bizitza politiko, sozial eta kulturaleko adierazpen guztiez daukan erabakitzeko eskubidearekin berdintzen da, eta hor herriko hiritar guztiak sartzen dira, nazionalista direnak eta ez direnak. Bide politiko instituzionalen bideak gainditzen dituen eskubide demokratiko hau euskal subiranotasunaren ikur bihurtzen ari da. ${ }^{14}$

Ez dakigu Zubiagaren aipuan azaltzen den «herri» hori zer den, ethnosa ala demosa, demosek bere baitan urtutako ethnosa, ala beti bilakabidean dagoen egiazko errealitate historikoa. Aipuko «nazio-identitate finkoak» eta " "nazio" hitza, jadanik baden komunitate objektibo gisa ulertuta» adierazpide horiek ez ote dute ezkutatzen nazionalismoari egotzi izan zaion esentzialismo-salaketa? Hori al da nazionalismo zibiko eta etnikoaren arteko kontraesana gainditzeko modua? Demokrazia zuzenaren izenean aldarrikatzen den transbertsalitate horretan nola eta zertan bateratzen dira estatu multinazionaleko subiranisten eta nazio menperatuetako independentisten xedeak?

Autoritate akademikoaren itzala daramaten pasarte solte horiek nahiko garbi adierazten dute nazioari buruzko azalpenetan tradizio modernoko diskurtsotik postmodernismorako jauzia ematen dela. Demokraziaren birformulazioan ezartzen da nazioari buruzko diskurtsoa, baina, mundu zabalean gertatzen ari direnak ikusita, ez dirudi hain formula arrakastatsua gertatzen ari denik, ez nazio-arazoari irtenbide egoki bat emateko, ezta gizarte-izatea bermatzeko ere.

\footnotetext{
más, la razón para abandonar la autoidentificación como 'nacionalistas vascos', en tanto en cuanto categoría subalterna, solo funcional en el ámbito de una política de reconocimiento externo.» (Zubiaga 2014b)

14 «La cerrazón hostil de los gobiernos españoles a toda reconciliación y proceso de paz abre sin embargo una vía de acceso a los segmentos vascos no soberanistas: la de la democracia. El discurso del derecho a decidir de organizaciones transversales y no partidarias como Gure Esku Dago es por ello sobre todo democrático: la soberanía equivale al derecho a decidir sobre todas las expresiones de la vida política, social, cultural, de todo colectivo, lo que abarca a todos los ciudadanos del país, nacionalistas o no. Este derecho democrático, que desborda los cauces político-institucionales, se está convirtiendo en la bandera de la soberanía vasca.» (Letamendia 2014)
} 


\section{Azken ondorio batzuk gogoeta gisa}

Bat. Iraultza burgesaren ondoko estatu multinazionalaren eredu historiko horrek aspaldi samar ezagutu zuen bere porrota eta, ondorioz, gero eta sostengaezinagoa gertatzen ari da haren balioa inbokatzen jardutea. Partidukraziak eta sindikatukraziak, batetik, eta, bestetik, estatuen atzean ezkutatzen diren lobby ikusezinek sistemaz hipotekaturik dauzkate herritarren eta hiritarren eskubideak. Bortxa eta gatazkaren gainean sasiplanteamentuak egiten dira, ontzat ematen baita gizarte-errealitatearen funtzionamendua ordenan oinarritzen dela eta, ondorioz, legez ezarritako ordena horretatik ateratzen den oro -tartean estatu-bortxari kontrajartzen zaion beste edozein bortxa mota- kondenagarria gertatzen dela. Ikuspegi funtzionalista honetatik begiratuta egiten diren azterketek desbideratuak dirudite eta, gure kasura etorrita, ez bide du zentzurik biktimez, damuaz, bakeaz eta justiziaz jarduteak, horrela arrazoitzean euskal nazioaren zapaltzaile estrukturala den estatu-diskurtsoan barneratzen garelako eta, logika honetan, nazio zapaldua estatu zapaltzailearekiko egoera defentsiboan jartzera behartzen gaituztelako. Horrela jokatzean, ez herri erresistente historiko baten, hots, bere askatasunaren bila doan subjektu historiko eraldatzaile eta oldartu baten aurpegia, baizik eta, oso alderantziz, koldartutako esklabo baten irudi etsia erakusten da. Teoria konfliktualistak gizarte-protagonisten interes-mundu kontrajarriak jartzen dizkigu begien aurrean eta bere estatu independentea izateko apustua egina daukan euskal nazio batek bere interesak eta xedeak —batez ere, lurraldetasuna, euskalduntasuna eta gizarte-berdintasuna- zaindu behar ditu, bere errebindikazioetan ingurune partikularretik abiatuz, ez estataletik. Maila hauetan jantzi behar da euskal nazioa edukiz eta zentzuz, euskal estatuak bere izateko arrazoia izan dezan. Orduan uztartuko dira errebindikazio berean herritasuna eta hiritartasuna.

Bi. Orain arte nazio-arazoaz egindako irakurketa, zeinetan nazionalismo zibikoa eta etnikoa kontrajartzen baitziren, gainditutzat ematen da. Jarraitu beharreko eredua, jadanik Kanpionek ere aipatzen zuena, ez da jakobinoa, nazionalismo liberal anglosaxoia baizik, bere garaian Ameriketako Estatu Batuetan eta gero Kanada, Eskozia eta Alemanian aplikatzen dena.

Baina hori esanda ere, arazoa maila praktikoan lehen bezain zintzilik gertatzen da. a) Nola bideratu behar da prozesu subiranista baldin estatu espainola ez bada demokrata, ez badu demokratizatzeko bokaziorik? b) Demagun demokratizatzeko bidean jartzen dela, zerk bermatzen du estatu demokratizatuak onartuko duela herri-borondatearen emaitza demokratikoa? c) Diskurtso honetan, nahiz nagusitzen den kontzeptua «hiritarrena» den, batzuetan «herriarena» azaltzen da. Biak modu nahasian erabiltzen dira, herriak etniarekin baitu zerikusi zuzena eta hiriak, aldiz, bere erabilera juridiko-politikoan, estatu-botereari atxikiriko atributuarekin. Azken zentzu honetan, hiritarra estatu jakin bateko kidea da eta, hala den aldetik, haren legerian alda- 
rrikaturik datozen eskubide eta betekizunen jabea da. Estaturik gabeko nazio batean herritarrak eta hiritarrak koexistitzen dira, baina ez maila etiko eta juridiko berean. Izan ere, Euskal Herrian herritarrak eta hiritarrak daude, eta azken hauen artean espainolak edo frantsesak sentitzen direnak eta ez direnak, Iparraldean alderdi frantsesak eta alderdi nazionalistak dauden bezala. Oinarrian, gure diskurtso osoan zehar esaten etorri garenez, eguneroko praktika politikoan nazio-ikuspegi antagonikoen arabera funtzionatzen duten alderdi estatalak eta ez-estatalak dauzkagu antolaturik, zeinaren arabera nazio menperatuetako hautesleak estatu zentralistarekin identifikaturik sentitzen baitira eta bere hiritartasunak estatuarekiko fideltasuna inplikatzen baitu. Bestalde, alderdi nazionalisten artean egon daitezkeen barne kontraesanak -nazionalak zein sozialak- bigarren mailakoak dira. Baina ez horregatik garrantzi gutxiagokoak, zeren nazio-gatazkak izaten direnean, interes sozioekonomikoak ere nahasten baitira. Honek esplikatzen du alderdi nazionalista autonomistek zergatik paktatzen duten sistemaz alderdi estatalekin gobernatzeko orduan.

Hiritartasunaz aritzean, bada, erakunde politiko estatalen eta ez-estatalen arteko bereizketa hau elementu determinatzailea gertatzen da Euskal Herriaren orainaz eta etorkizunaz erabakiak hartzeko orduan. Ez da nahikoa esatea gizon-emakumeen eta hiritarraren eskubideak Frantziako Iraultzaz geroztik onartuak daudela eta, printzipio mailan, hiritar bakoitzari —nonahi jaio den edota bizi den hiritar orori bezala - dagozkion eskubide indibidual eta kolektiboak unibertsalak eta besterenezinak direla. Ez da nahikoa, ezta ere, estatu batzuek, Quebec edo Eskoziaren kasuan bezala, onartzen dutela herri baten erabakitzeko eskubidea. Ohikoena alderantzikoa gertatzea baita, hots, hiritartasunaren adiera zein erabilera estatuak monopolizaturik dauzkala.

Hiru. Ikusiz etorri garen bezala, nola foru-tradizioan hala nazionalismo historikoan euskal naziotasuna Euskal Herri historikoaren ezaugarri etnikolinguistikotik eta lurralde-kokapenetik abiatuta definitu izan da eta geroztik naziogintza, euskalgintza eta lurraldetasuna ikuspuntu historiko horretan oinarritu izan dira. Eta horretan saiatu izan gara. Nazionalismo etnikoaren argitan ikusi izan da euskal nazioaren eduki kulturala, hizkuntzaren normalizazio-prozesua eta lurralde-batasuna. Euskal errebindikazioen subjektua elementu aldi berean objektibo eta subjektiboetan oinarrituta zegoen.

Estaturik gabeko nazioari «irudikatua» ere deitzen zaio, baina horrek ez du esan nahi irreala edo fantasmatikoa denik; aitzitik, nazio irudikatu hauek beren oinarri objektiboa dute, historia, hizkuntza, etnia eta erlijioan oinarritzen dena.

Lau. Azkenaldion, ordea, erabakitzeko eskubideaz eta hiritarren eskubide demokratikoaz jardutean, subjektutzat, ez hainbeste elementu objektiboak — komunitate etniko bati dagozkion ezaugarri etnikoak-, baizik, eta batez ere, subjektiboak aipatzen dira, hiritarren borondatean eta erabakime- 
nean oinarritzen direnak. Badirudi, ikuspegi honen arabera, orain arte nagusitu izan den etnokrazia edo herritartasuna gaindituz, ikurtzat demokrazia edo hiritartasuna hartu dela eta horren argitan bideratu dela egungo euskal politika, baita euskal ezkerrean ere. Indibidualismoaren garaipena da hau. Herri zapaldu baten eskubide historiko kolektiboak alde batera uzten dira, hiritarren identitateak erro edo memoria historikorik ez du, egunean eguneko hiritarren borondatean bakarrik kokatzen baita erabakitzeko eskubidea. Erabakitzeko eskubide honetan, bestalde, ez dakigu zer lehenetsi, eskubidea bera ala erabakimena. Hizkuntzek eskubiderik ez dute, hiztunek baizik. Kolektibotasunaren adierazle diren kontzeptuak, hala nola estaturik gabeko nazioak, gutxiengo etniko-linguistikoak, lurrik gabeko komunitateak, langabezian daudenak eta, ez dira existitzen.

Transkribatu eta aipatu ditugun testu horiek nahasgarri eta ilunak dira, ez baitakigu zein eduki zehatz duten. Azken batean ez dakigu euskal estatu hipotetiko batean Euskal Herri euskaldun batekin ala, gaurkoaren antzera, euskal gizarte funtsean erdaldun batekin konformatzen garen, gaztelera eta frantsesa euskara bezain gureak eta bertakoak ote diren edo, bestela esanda, euskara gure hizkuntza nazionala den ala ez, ez dakigun bezala hiritartasuna eta herritasuna gauza berbera diren edo, bestela esanda, beren identitate espainola edo frantsesa errebindikatzen duten hiritarrak - bertakoak zein bertakotuak- euskal subiranotasun-subjektutzat hartu behar diren ala ez, bi estatu multinazionaletan zatitutako euskal lurraldearen batasunari, berreuskalduntzearen kasuan bezala, erabateko lehentasuna eman behar zaion ala ez. Helburuak ez badaude garbi, dena aldian aldiko prozesu eratzailearen esku utzi behar bada, zerk justifikatzen du euskal estatu independente baten beharra?

Bost. Erakunde estatalen eta ez-estatalen arteko bereizketa kontuan hartu beharrekoa da. Bestela esanda, estatalak nazio politikoari dagozkionak dira; ez-estatalak, berriz, nazio kulturalari dagozkionak. Guk horrela ulertu ditugu azalpen honetan, oinarritzat, funtsean, Gemeinschaft eta Gesellschaft kontzeptuen arteko bereizketa hartuta.

Egin beharreko oinarrizko lehen bereizketa, alderdi eta mugimendu estatalen eta ez-estatalen artekoa da. Maila honetan, alde batean, estatu-lurralde osora hedatzen direnak aurkitzen dira, hala nola alderdi liberalak, errepublikanoak, kontserbadoreak, sozialistak, foruzaleak, eta bestean nazionalista, euskaldunak, katalanak, eta beste.

Hori esanda, gaineratu behar da estatu-erakunde horien «nazio» edo «nortasun» kontzeptua funtsean «espainola» den nazio politikoan oinarritzen dela, zeinaren arabera XVI. mendeaz geroztik eraikiz datorren estatu espainola baita nazio espainola - espainiartasuna- eraikitzen duena. Beste maila batean, ordea, ezin dugu gauza bera esan euskal foruzaletasun mota desberdinez, zeren, nahiz eta hauek beren errebindikazio politikoak estatu 
espainolaren barruan planteatzen dituzten, beren nortasun-ezaugarria, ez estatu multinazionalean, baizik foru-nortasunean oinarritzen baita. Bereizketa hau egin beharrekoa da. Honek esan nahi du gerra karlistek ezaugarri bereziak izan zituztela Euskal Herrian eta Espainiako beste lurraldeetan, ez zela soilik gerra dinastikoetara, edo erlijio-arazora, edo arlo sozialera mugatu, foruetara baizik, bederen Euskal Herrian.

Euskal nazionalismoa bakarrik da alderdi estatalen eta ez-estatalen artean nazio-muga ezartzen duena eta, bide batez, euskal nortasunaren funtsa, ez estatu multinazionalean, baizik nazio kultural euskaldunean, ezartzen duena, non euskal nazioa osatzen duten beste elementu guztien gainetik euskara baita elementu osatzaile ez bakarra, baina bai nagusia. Kataluniaren kasuan, adibidez, ezin argiago ikusi da alderdi eta erakunde estatalen jokabidea. Guztiek hiritarren erabakimenaren aldekotzat jotzen dituzte beren buruak, baina aldi berean independentziaren kontrakoak direla esango dute. Oso demokratak, bai, baina espainolak, beren nazio nagusitzat Espainia dutenak.

Euskal Herrian sortu eta finkatu ziren erakunde estatalek, liberalek zein sozialistek, erabat bazter utzi zuten euskal arazoaren alderdi nazionala bere dimentsio politiko, kultural eta linguistikoan. Dena, Unamunoren kasuan bezala, unibertsalismo gaizki ulertuak eraginda. Euskal Herriko sozialismoan Eibarko eredua zabaldu eta indartu izan balitz, agian, beste txori batek kantatuko zuen. Tomas Meabe eta Toribio Etxebarriaren ereduak izan zitezkeen ekarpen interesgarriak, baina haien ahalegina, azken batean, euskal gizartearena baino zabalago eta unibertsalagoa zen estatu-politika espainolean urtuta geratu zen. Gaur arte.

Dena den, nazio-arazoari dagokionez, euskal politikagintza ez da mugatzen soilik alderdi estatalen eta ez-estatalen arteko harremanetara. Klasearteko interesek ere badute beren eragin eraginkorra eguneroko praxi politikoan. Ez da kasualitatea euskal nazionalismo historikoak garaian garaiko alderdi estatalekin hitzartzea —egun EAJk PSOE eta PPrekin bezala-, eta ezkutuko hitzarmen horren ondorioz independentziari sistemaz uko egitea. Aski du autonomiarekin eta aldebiko estatutuaren errebindikazioarekin Espainian eroso sentitzeko. Ulertzekoa da, beraz, azkenaldiko katalanen alde bateko hautuak zalantza-bidean jartzea.

Sei. Mugimendu etiko modernoen —eta zehazki euskal nazionalismoaren- inguruan mamu beltz asko hedatu da. Horietako batzuk epistemologiaren zola ukitzen dutenak dira, neurri handiagoan edo txikiagoan ontzat ematen direnak, baina auzitan jarri beharrekoak direnak.

Hor sartzen da, adibidez, Tzvetan Todorovek Nous et les autres (1989) liburu aipatuan etnozentrismoaz egiten duen irakurketa. Autore honen ustez, etnozentrismoaren fenomenoa gauzatzen da partaide gareneko gizartearen 
balioak unibertsalen kategoriatzat bidegabeki hartzen direnean. Etnozentrista, bada, unibertsalistaren berezko karikatura bat da. Unibertsalera jotzeko partikularra den zerbaitetik abiatzen da eta, hala egitean, berehala ahalegintzen da bere partikularra orokortzen, hots, unibertsalizatzen. Horregatik, etnozentrismoak bi aurpegi ditu: batetik, asmo unibertsalak gidatzen du eta, bestetik, eduki partikularra du, sarritan nazionala baino ez dena. Zenbaitetan mintzaira bera unibertsaltzat hartua izan da, zergatik eta arrazoiaren mintzaira delako. Hortik dator nazionalismo etnikoa etnozentrismoarekin berdintzea.

Jadanik XVIII. mendean hainbat autorek egin zuten kontzeptu horren kritika; besteak beste, Fontenelle, Montequieu eta J.-J. Rousseauk. Honentzat «desberdina den hartatik berezkoa aurkitzea etengabe errebindikatu izan den zerbait da». Honek partikularraren eta unibertsalaren arteko mugan jartzen gaitu, muga ilun eta arriskutsu batean. Rousseauk uste du etnozentrismoa ebidentzia faltsu batetik abiatzen dela, zeina baita unibertsala partikular batetik eratortzen dela suposatzea. Todoroven ustez, Rousseauren oharra jasoz, unibertsala, izan, bi partikularren arteko harmoniaren horizontea izanen litzateke; agian, inoiz ez da iritsiko hartara, baina partikular horiek ulergarri izan daitezen, harmonia postulatu beharra dago.

Hor airetik barna libre dabilen beste iratxo bat nazionalismoaren protagonismo burgesaren salaketarena edo funtzionalismo ekonomikoarena da, marxismo klasikoak sistemaz egin izan duena, non baieztatzen baita klaseinteresak nagusitzen direla manipulazio politiko eta arbitrarietate etnikoen gainean.

Areago joanez, nazionalismo etnikoari egozten zaion beste ezaugarri bat esentzialismoarena da, zeinaren arabera mugimendu nazionalisten errebindikazio politikoak lehendik existitzen diren ustezko elementu objektibo historikoetan oinarritzen baitira:

Soziologoa ezin da abiatu Nazioa errealitate objektibo, natural, transhistoriko baten emanazio subjektiboa delako eta historia entitate objektibo hori politikoki nola iristen den objektibatzera dioen historia delako ideiatik. Soziologoak ezin du erreproduzitu, maila espekulatiboan, Nazioaren a priorizko nozio bat elementu objektiboen terminoetan definituz (...) Hau da arbitrarietatearen lehen zentzua: ezaugarri objektiboetan oinarritutako 'priorizko kontzeptu' bat eraiki ezin badugu, ezingo dugula, ezta ere, aurresan, ezaugarrien existentzian oinarrituta, kolektibo bat noiz definituko den hitz nazionaletan, eta, hala mugatzean, noiz izango duen arrakasta soziala. (Pérez-Agote 1989: 189-190)15

15 «El sociólogo no puede partir de la idea de que la Nación es una emanación subjetiva de una realidad objetiva, natural, transhistórica y de que la historia es la historia de cómo esta entidad objetiva llega a objetivarse políticamente. El sociólogo no debe reproducir, especularmente, una no- 
Salaketa hauen oinarrian komunitate jakin bati egozten zaizkion unean uneko elementu subjektibo eta boluntaristak aurkitzen dira. Azken finean, Weberrek eta Durkheimek gizarte-ekintzari buruz egiten duten definizioan aurkitzen da, non lehen kasuan abiapuntua elementu indibidual eta subjektiboetan ezartzen baita eta bigarrengoan, aldiz, kolektibo eta objektiboetan. Guretzat biak dira osagarriak. Gai honetaz luza jardunak gara «Euskal nortasunaren bila: topaketa kritikoa» lanean (Iztueta 1998: 17-95) eta ZABALen isuria (1973-1976). Ezker abertzalea paradigma berrien aurrean liburuan (Iztueta 2015: 17-89), eta iturri horietara igortzen dugu irakurle interesatua. Nolanahi ere, gogoan hartzekoa da gizarte-zientzietako azterketetan estatu multinazionaleko intelligentsia organikoen hizkuntzari ematen zaion garrantzia, Tiryakianek (1989: 158-159) azpimarratzen duen bezala:

Hau da, gizarte-zientzialariek nazionalismo zeltaz (galestarraz, eskoziarraz) edo euskal nazionalismoaz, edo nazionalismo katalanaz, edo Quebeceko nazionalismoaz, edo nazionalismo korsikarraz idazten dutenean, eta «nazionalismo etikoa», «nazionalismo etnoerregionala», «azpinazionalismoa» moduko kuantifikatzaileak erabiltzen dituztenean, honela egiten dute funtsean ezarritako estatu-nazioaren joko honi jarraituz: hots, barruko mugimendu nazionalistak, nolabait, ez direla «benetako» nazionalismoa bezain egiazkoak, esanguratsuak, baliozkoak, garrantzitsuak, etab. Beste era batera esanda, mugimendu horiek ez dira benaz hartu behar. Horixe da estatu-nazioaren jokoa. ${ }^{16}$

Nolanahi ere, mugimendu nazionalisten errebindikazioak ez direla «seriotan» hartzekoak esaten bada ere, estatu multinazionalak, badaezpada, neutralizatzeko neurri desberdinak erabil ditzake; horien artean komunikabideen kontrola eta bortxaren erabilera edota, independentziaren aldeko erreferendumen kasuetan, baita erabaki horrek maila ekonomikoan ekar litzakeen ondorio negatiboen iragarpen negatiboa ere:

Masa-hedabideen kontrola nazionalisten kexak blokeatzeko modu oso eraginkorra da. Estatu-nazioaren biolentzia estal daiteke; naziona-

\footnotetext{
ción a priori de Nación, definiéndola en términos de elementos objetivos (...) Este es el primer sentido de arbitrariedad: si no podemos construir 'un concepto a priori' basado en rasgos objetivos, tampoco podemos predecir, en base a la existencia de rasgos, cuándo un colectivo va a definirse en términos nacionales, y cuándo, al hacerlo, va a tener éxito social.» (Pérez-Agote 1989: 189-190)

16 «Es decir, cuando los científicos sociales escriben sobre el nacionalismo celta (galés, escocés) o el nacionalismo vasco, o el nacionalismo catalán, o el nacionalismo de Quebec, o el nacionalismo corso y usan cuantificadores como 'nacionalismo étnico', 'nacionalismo etnoregional', 'subnacionalismo', etc., esencialmente siguiendo el juego del estado-nación establecido de que los movimientos nacionalistas internos son de alguna manera, menos auténticos, menos significativos, menos valiosos, menos importantes, etc., que el nacionalismo 'verdadero'. Dicho de otro modo, que estos movimientos no deben tomarse en serio. Este es juego del estado-nación.» (Tiryakian 1989: 158-159) [Larraitz Zubeldiak euskaratua].
} 
lista batzuen biolentziaren erabilera, berriz, «terrorismo» eta «estremismo»tzat hartzen da, eta «Elezahar Beltza»ren irudira jotzen da hala. Edo, halaber, eboluzioa onartzeko plebiszitua egiten denean (Eskozia, Gales eta Quebeceko erreferendumetan bezala), estatuak botoemaileak presiona ditzake sotiltasunez, iradokiz litekeena dela gizarte segurantza edo pentsiorik ez jasotzea, itzultzea estatu-nazioak onartzen ez duen eran gauzatzen bada. (Tiryakian 1989: 158-159) ${ }^{17}$

Berrikitan, Kataluniaren kasuan, konstituzioko 155. artikulua inbokatuz, estatu espainolak neurri hertsatzaile horiek guztiak hartu dituela esan ezinik ez da, helburutzat beldurra eragitera zuzenduta daudenak (Fernandez 2017). Aurrerantzean ere, menpeko nazioen askapen-prozesu geldiezinek, handituz doazenek, estatu multinazionalen neurri zapaltzaileekin kontatu beharko dute, eta horri erresistentziaren bidez aurre egiteko herri-mugimendu desberdinen parte-hartzea beharrezko dute bertako erakunde politiko-sindikalek. Orduan hartuko du demokraziak bere zentzu osoa, herritarrek eta hiritarrek batera dutena hartuz eta egiazko komunitatea eraikiz.

Zazpi. Utopia al da estaturik gabeko nazioen independentzia? Estatu multinazionalen erantzuna argia da: erabat ezina. Konstituzioetan autodeterminatzeko eskubidea ez datorrela jasoa eta, legezkotasunik ezaren arrazoiarekin erantzuten da. Baina historiak besterik frogatzen du. Europan xx. mende hasieran 24 estatu ziren eta egun 50etik gora dira, zehazki 28 hauek: Estonia (1990), Letonia (1990), Lituania (1990), Bielorrusia (1991), Moldavia (1991), Ukraina (1991), Georgia (1991), Armenia (1990), Azerbaijan (1991), Turkmenistan (1991), Kazakhstan (1991), Kirgizistan (1991), Tajikistan (1991), Uzbekistan (1991), Eslovenia (1991), Kroazia (1991), Bosnia-Herzegovina (1991), Mazedonia (1991), Montenegro (2006), Serbia (1992), Kosovo (2008), Iparraldeko Zipre (1960), Karabakh Garaia (1991), Hego Osetia (1991), Transnistria (1990), Abkhazia (1992), Txekia (1992), Eslovakia (1992) eta Donbass (2014). Estatu berri hauek SESB eta Jugoslavia desegin zirenean eta Txekoslovakia bitan zatitu zenean agertu ziren, 1990eko hamarkada hasieran (Susaeta 2017). Zerrenda horretan, egun Katalunian bezala, 27 estatu izan ziren bere garaian independentziarako alde bakarreko aldarrikapenaren bidetik abiatu zirenak eta horietatik 19 izan ziren Nazio Batuen onarpena lortu zutenak; beste 7 hauek, hots, Moldavia, Hegoaldeko Zipre, Karabakh Garaia, Hegoal-

\footnotetext{
17 «El control de los medios de masas constituye un modo de bloqueo muy efectivo para las quejas de los nacionalistas. La violencia del estado-nación se puede tapar mientras que el uso de la violencia por algunos nacionalistas se tacha de 'terrorismo' y 'extremismo', abocando así la imagen de la 'Leyenda Negra'. O también cuando se celebra un plebiscito para conceder la evolución (como en los casos de referéndum en Escocia, Gales y Quebec), el estado puede presionar sutilmente a los votantes sugiriéndoles que quizás no se reciba seguridad social o pensiones si la devolución aconteciera en líneas no aprobadas por el estado-nación.» (Tiryakian 1989: 158-159) [Larraitz Zubeldiak euskaratua].
} 
deko Osetia eta Transnistria. Abkhazia eta Donbassek, berriz, onarpen hori jaso gabe jarraitzen dute (Gara, 2017-10-28).

Azkenaldion Europako mapan agertu diren estatu berri horiek adierazten dutena da nazionalismo kulturalak suspertuz doazen heinean estatu multinazionalek osatutako Europako Batasuna krisi sakona jasaten ari dela eta, bidenabar, Europako mapa politikoa estatu berrien presentziaz koloreztatzen doala.

Donostian, 2017ko azaroaren 1ean.

\section{Erreferentzia bibliografikoak}

ARIAS, Hector (2003), «Estudio de las comunidades». In Rayza Portal \& Milena Recio (arg.), Comunicación y comunidad. La Habana: Editorial Félix Varela.

ARTAUD, Antonin (1979), Messages révolutionnaires. Paris: Gallimard.

BIDEGAIN, Eneko (2014), «Estatugintza eta herrigintza». Nabarralde 90: 3.

Bourdieu, Pierre (1979), La distinction. Paris: Minuit.

ConNor, Walker (1987), «Ethnonationalism». In Sonuel Huntongton \& Myton Weiner (arg.), Understanding Political Development. Boston: Little, Brown and Company.

ConNor, Walker (1989), «Democracia, etnocracia, y el estado multinacional moderno: paradojas y tensiones». In Alfonso Perez-Agote (arg.) (1989), Sociología del nacionalismo. Bilbo: Eusko Jaurlaritza eta EHUko Argitalpen Zerbitzua, 111-130.

DurKheIM, Emile (1987), Las reglas del método científico. Madril: Akal.

FERNANDEZ, Jon (2017), «Beldurraren estrategia ekonomikoa». Berria, 2017-10-29.

IZTUETA, Paulo (1988), «Euskal nortasunaren bila: topaketa eta kritika». In Joxe Azurmendi (zuz.), Hizkuntza eta talde-nortasuna. Donostiako Udako XII. Ikastaroak. Bilbo: EHUko Argitalpen Zerbitzua, 17-95.

Iztueta, Paulo (2000), Hezkuntza, hizkuntza eta boterea. Donostia: Utriusque Vasconiae.

IzTUeTA, Paulo (2002), «Nazio kultural euskaldunaren aurrerabideaz». Euskal Kulturgintzaren Transmisioan Aditu Tituluan emandako hitzaldia, Mondragon Unibertsitatea.

IzTUETA, Paulo (2015), ZABALen isuria (1973-1976). Ezker abertzalea paradigma berrien aurrean. Donostia: Utriusque Vasconiae.

KrUTwig, Federiko (1962), Vasconia. Estudo dialectico de una nacionalidad. Sarrailh de Ihartza (arg.). Buenos Aires: Norbait.

KRUTWIG, Federiko (1964), Manifiesto por la Etnocracia.

LARRAmend, Manuel (1766-68 [1983]), Sobre los fueros de Guipúzcoa (J. Ignacio Tellechea (arg.). Donostia: Sociedad Guipuzcoana de Ediciones y Publicaciones.

LeTAMENDiA, Francisco (2014), «Soberanía permanente y derecho a decidir». Gara, 2014-11-11.

NielsSon, Gunnar P. (1989), «Sobre los conceptos de etnicidad, nación y estado». In Alfonso Perez-Agote (arg.) (1989), Sociología del nacionalismo. Bilbo: Eusko Jaurlaritza eta EHUko Argitalpen Zerbitzua, 193-225.

Odriozola (2017), «Ethnosa versus demosa». Berria, 2017-09-11: 23. 
Orella, José Luis (2014), «La patria no se hereda, sino que se elige». Gara, 201412-18.

Perez-Agote, Alfonso (arg.) (1989), Sociología del nacionalismo. Bilbo: Eusko Jaurlaritza eta EHUko Argitalpen Zerbitzua.

Rousseau, Jean-Jacques (1762), Du Contrat Social. Du Contra social. Principe du droit politique. In Gérard Mairet (1978), Les doctrines du pouvoir. Paris: Idées Gallimard. Euskarazko itzulpena: Oyharçabal, Bernard (1993), Gizarte-Hitzarmena. Bilbao: Klasikoak.

Ruiz Olabuenaga, J. I. (1989), «Reproducción étnica en el País Vasco: dinámica y proceso». In Alfonso Perez-Agote (arg.) (1989), Sociología del nacionalismo. Bilbo: Eusko Jaurlaritza eta EHUko Argitalpen Zerbitzua, 131-139.

SANZ MoReno, José (2017), «Ciudadanía, identidades nacionales, inmigración y respuestas democrática». Internetetik 2017-10-27an jaitsia.

SOCARRAS, Elena (2004), «Participación, cultura y comunidad». In Cecilia Linares Fleites, Pedro Emilio Moras Puig \& Bisel Rivero Baxter (arg.), La participación. Diálogo y debate en el contexto cubano. La Habana: Centro de Investigación y desarrollo de la cultura cubana Juan Marinello, 173-180.

SoTо, Mikel (2014): «Pankarta baten historia». Gaur8, 2014-10-11.

SusAeTA, Igor (2017), «Desegiteek koloreztatua». Berria, 2017-10-29.

Tiryakian, Edward A. (1989), «Nacionalismo, modernidad y sociología». In Alfonso Perez-Agote (arg.) (1989), Sociología del nacionalismo. Bilbo: Eusko Jaurlaritza eta EHUko Argitalpen Zerbitzua, 143-162.

Todorov, Tzvetan (1989), Nous et les autres. Paris: Seuil. Gaztelaniazko itzulpena: Nosotros y los otros. México: Fondo Cultura Económica.

Todorov, Tzvetan (2010), L'expérience totalitaire: la signature humaine. Paris: Éditions du Seuil.

Zubiaga, Mario (2014a), «¿Queremos?». Gara, 2014-06-15.

ZubiagA, Mario (2014b), «Zeitgeist». Gara, 2014-10-11.

ZubiaGA, Mario (2014c), «Kuntza-tik gintza-ra». Gara, 2014-11-30. 